\title{
Species Richness and Diversity of Land Snails in Ngel-Nyaki Forest Reserve, Mambilla Plateau, Taraba State Nigeria
}

\author{
RONALD Winifred Isemobhita Abhulimen ${ }^{1 *}$, WALSON Fate ${ }^{2}$ \\ $1 *$ Department of Biological Sciences, Federal University Wukari, Nigeria. \\ ${ }^{2}$ Department of Animal and Environmental Biology, University of Benin, Nigeria \\ DOI - http://doi.org/10.37502/IJSMR.2021.4709
}

\begin{abstract}
The need to identify and estimate the montane forest for bio-diversity conservation in Nigeria has become of utmost importance due to the fact that the tropics have faced massive biodiversity loss due to intensive anthropogenic activities. Molluscs are among the most ancient of animals on earth today. Nigeria Plateau has long been recognized for its faunal richness and diversity. This study established the molluscan compositions in relation to the soil content that influence the distribution of molluscs fauna of the plateau montane forest of Taraba State, Nigeria. The land snail richness and diversity of Mambilla plateau montane forest, Ngel- Nyaki, was studied using a combination of direct search and litter sieving techniques. Twenty-four plots of $20 \times 20 \mathrm{~m}$ were randomly selected. A total of 18 species and 681 individuals in 7 molluscan families were recorded from 24 plots. The carnivores Streptaxidae and Subulinidae dominated the land molluscan fauna in the number of species. The non-parametric estimator of Chao 2 and jackknife were 17.985 and 18.10 of all sample collected. Nitrogen content in the soil of the montane forest was $7.25 \mathrm{gkg}-1$. Terrestrial mollusk with small populations and narrow distributional ranges are at a great risk of local extinction if forest destruction continues unabated. The land snail species inventory increased our knowledge of the molluscan fauna of the montane forest and also assisted in biodiversity conservation management in Nigeria.
\end{abstract}

Keywords: Mollusc, Biodiversity loss, Conservation, Diversity index, Montane forest.

\section{Introduction}

The tropics have faced massive biodiversity loss due to intensive anthropogenic activities such as changes in land use and degradation of the environment. Recent reports suggest that the tropics are losing biodiversity at an alarming rate (Sodhi, 2008). Much of this biodiversity loss has been reported for vertebrates and plants. However, there is very little knowledge on the extent of loss in lesser known groups, especially the invertebrates (Lydeard et al., 2004).

Conservation of wildlife species are maintained at the optimum level commensurate with other forms of land use and human activities in order to ensure continued existence of wildlife for the benefit of the people (Nigeria National Park Service, 2006). Although individual nations designate their own national parks differently, there is a common idea; the conservation of wild nature for posterity and as a symbol of national pride (Nigeria National Park Service, 2006). Land snails include several distinct lineages of terrestrial gastropods and belong to the second largest phylum after arthropods in terms of number of species with more than one lack described species (Lydeard et al., 2004). Land snails constitute about six percent of the total species on Earth (Clark and May, 2002). 
Land molluscs are damp atmosphere animals, found in habitats such as banks of water courses and ponds, marshes, damp meadows, especially such that have dead leaves, tree stumps, rotten wood and thickets of vegetation. Welter-Schultes and Williams (1999) reported that habitat diversity affected species' richness even after accounting for the effects of area. In calcium poor habitats, land snails can form an important source of calcium for other animals. They also serve as an indicator of ecological conditions and are very sensitive to climatic and ecological change (Čejka and Hamerlík, 2009). Thus, they are useful for reconstructing past environments (Bar-Yosef, 2002). Globally, nearly 35,000 species of land snails have been described and there may be 30,000 to 60,000 additional species yet to be described (Lydeard et al., 2004). The documentation of the distribution and magnitude of biodiversity is an essential task for any program involving sustainable development and should be a fundamental part of each region's development (Mittermeier et al., 1998). Despite their ecological and economic importance, many species of molluscs are suffering from the threat of extinction (Lydeard et al., 2004). There are more recorded extinctions of land snails than for all other animal groups (Naggs and Raheem, 2007). This makes land snails a key group for recognizing why and where extinctions are taking place and also means that snails might act as the sensitive indicators of environmental change that are needed to demonstrate that conservation measures are effective. The speed with which the current episode of extinctions happened and continued to take place means that natural processes are negligible and losses in biological diversity are due to human impact on the environment (Naggs and Raheem, 2007).

A large part of molluscan fauna in many tropical regions of the world is still poorly known. They form an important component of the forest ecosystem by recycling nutrients (Graveland et al. 1994; Dunk et al., 2004) and are the prey base for a number of small mammals, birds, reptiles, amphibians and other invertebrates, including carnivorous snails (Deepak et al., 2010).

The major threats to the native land snail fauna include habitat loss and fragmentation as a result of anthropogenic activities such as intense land-use, construction of roads, dams, plantations, pollution and the spread of invasive species (Aravind, 2005). These reduce diversity and change the community structure of land snails (Rajashekhar and Aravind, 2012). Poor dispersal and narrow distribution ranges of many land snails have undoubtedly contributed to high levels of their extinction. Furthermore, because of their habitat preference, any disturbance could affect their gene flow. For instance, roads construction within a protected area system could fragment snail population. On one hand, for many forest snail species, man-made habitats such as gardens, parks, and plantations can act as either refugia or corridors between forest patches (Raheem et al., 2008).

Climate change is also considered a threat to many species (Thomas et al., 2004) including land snails (Bezemer and Knight, 2001; Gerlach, 2007). Changes in rainfall patterns and fluctuation in soil temperature could lead to the death of juvenile snails and impair mobility across a segmented mosaic of natural and transformed habitats in response to climate change. Extinction of land snail species due to change in climatic conditions such as a decrease in rainfall and global warming has also been reported (Baur and Baur, 1993; Gerlach, 2007).

Mambilla plateau is the highest plateau in Nigeria, with a mean altitude of about 1524 metres (5000feets) above sea level. The Plateau covers an area of 9389 square kilometers, found in South-eastern part of Taraba State of Nigeria, sharing border with Cameroon. It contains several afro-montane forest fringes scattered and spread across the Plateau and also harboring a lot of wildlife. With the increasing threats to biodiversity on the Mambilla Plateau conserving and restoring Ngel-Nyaki Forest Reserve is more important now than it has ever 
been. Yet despite its Forest Reserve Status the forest continues to be seriously threatened by cattle grazing, burning and other illegal activities (Ezealor, 2002).

The objective of this research was to study the land mollusc abundance and species richness in Mambilla plateau, Ngelyaki, Taraba state, Nigeria and compare the results obtained with those from other ecosystems in Nigeria and other countries.

\section{Materials and methods}

\section{Description of the study area}

Ngel-Nyaki forest reserve (henceforth NNFR) is located on the Mambilla Plateau $\left(07^{\circ} 14^{\prime} \mathrm{N} / 11^{\circ} 04^{\prime} \mathrm{E}\right)$ of Taraba State, Nigeria (Fig. 1). It lies on an altitude of 1,800 meters above sea level, having Afromontane climate. The NNFR is a mosaic of habitat containing grassland, forest, streams, valleys and gorges. The climate is seasonal with dry season lasting from November to March and rainy season from April to October with a mean annual rainfall of $1780 \mathrm{~mm}$. The NNFR is considered as a critical site for biodiversity conservation in Nigeria and globally (Ezealor, 2002), providing an opportunity for research studies on tropical biology and conservation.

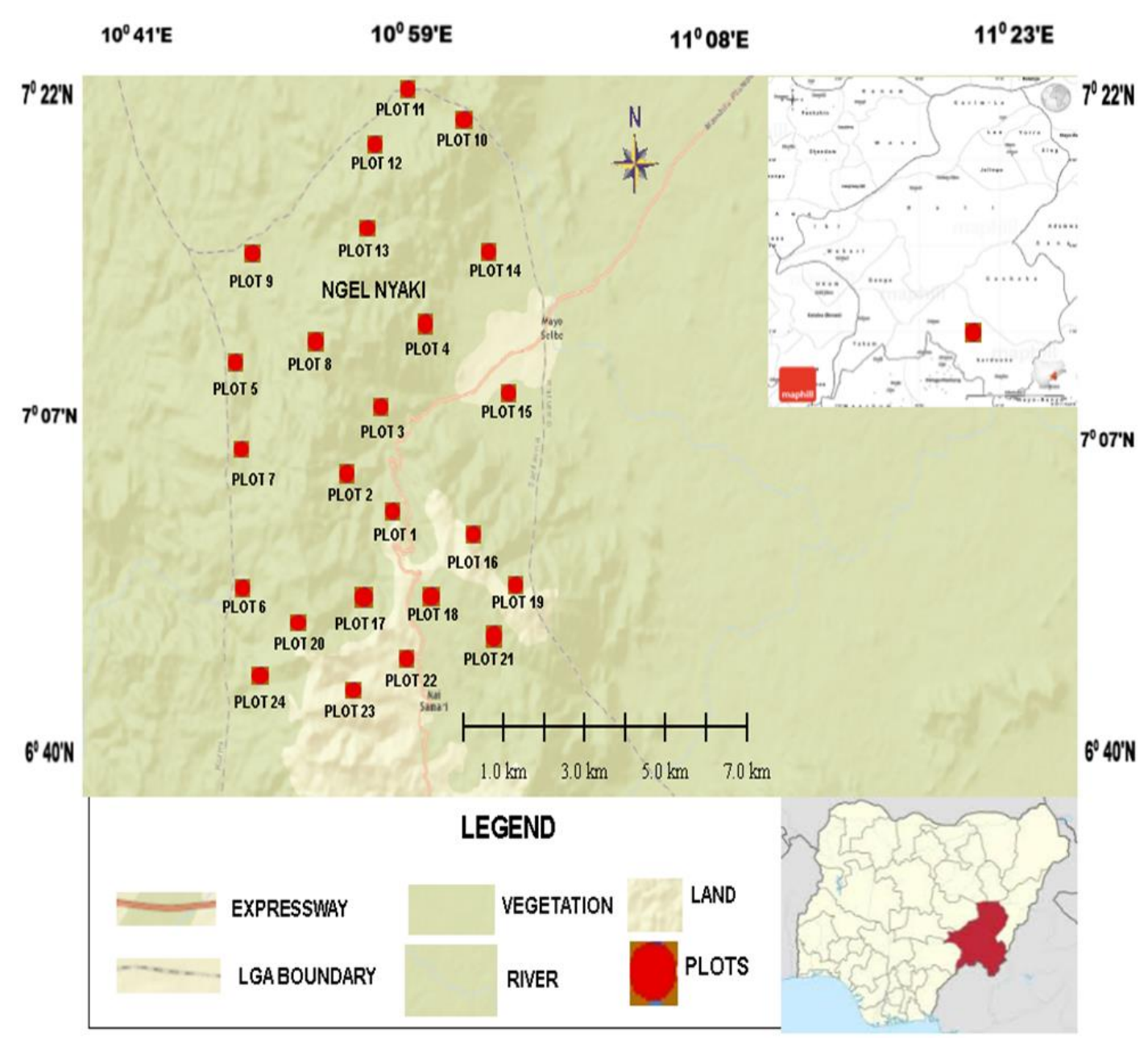

Figure 1: Map of Mambilla Plateau, Ngel yaki, Taraba state showing the 24 plots sampled. 


\section{Sampling}

Land mollusc samples were collected from the study areas using a combination of direct search and litter sieving techniques (Tattersfield, 1996). This was carried out in June, 2016, November 2016, April 2017, June 2017, October 2017 and February 2018. This method was designed to detect both large sized molluscs that often occur in low density and micro species that are often cryptic and litter dwelling (Winter and Gutten Berger, 1998).

Selected locations in the study area were sampled, and land snails were searched intensively by team members by a length of time. Litters and top soil were collected in bags, from randomly selected locations (1m x $1 \mathrm{~m}$ each) and was labeled with date and area of collection, and tied to prevent life snails from escaping.

All land snails, slugs and shell fragments encountered as well as those collected both alive and dead in the field were preserved in $70 \%$ ethanol after drowning. This was stored for future anatomical studies.

\section{IDENTIFICATION OF SPECIMEN}

\section{Laboratory Procedures}

Samples were slowly and completely dried in either a low-temperature soil oven (ca. 50-60 ${ }^{\circ} \mathrm{C}$ ) or in full sun in a greenhouse. Dried samples were then be soaked in water for 3-24 hours, and subjected to careful but vigorous water disaggregation through a standard sieve series (ASTME 3/8" (9.5 mm), $10(2.0 \mathrm{~mm}), 20(0.85)$, and $40(0.425 \mathrm{~mm})$ mesh screens). Sieved sample fractions were then dried and passed again through the same sieve series. These dry, resorted fractions were handpicked against a neutral brown background using a binocular microscope and a small sable brush. All shells and shell fragments were removed. The samples were archived in the University collections based in the ABM Egborge Museum, Department of Animal and Environmental Biology, university of Benin, Benin City, Nigeria. Identifiable shells were assigned to species (or subspecies). From this, the total number of taxa per plot was determined.

\section{Data analysis}

The diversity was measured as overall Species Richness $(S)$ and Whittaker's index $(I)$, which is the total number of species recorded $(S)$ divided by the mean number of species per site $(\alpha)$, providing a measure of diversity difference between sites (Schilthuizen and Rutjes, 2001). The true diversity was estimated by performing 100 randomizations on the data and calculating $S$ using the Chao2 and second-order jackknife richness estimators in the program Estimate $S 7.5$ (Colwell, 2006). Sample-based rarefaction curves were used to produce a smooth curve that estimated the number of species that would be observed for any smaller number of samples, assuming random mixing of sample order (Colwell and Coddington, 1994; Gotelli and Colwell, 2001). Statistical analyses were performed using the PAST software (Hammer et al., 2001).

\section{Results}

The study recorded 681 individuals of molluscs of 18 species belonging to seven families. The most dominant families are Streptaxidae and Subulinidae containing five species each, while the least species rich are Allyidae, Urocyclidae, and Veronicellidae with one species each. Table 1 shows the occurrence of land mollusc species from the 24 plots recorded in the 
study area. This ranged from 9 to 70 individuals per plot $($ mean $=28.38 \pm 14.01)$ and 3 to 12 species per plot $($ mean $=6.96 \pm 2.05)$.

Table 2 shows the quality of the soil analysed from Mambilla Plateau Montane forest (MPMF), the $\mathrm{pH}$ value of the water was 5.3, slightly acidic while the nitrogen content was $7.25 \mathrm{~g} / \mathrm{kg}$. The calcium and phosphorus content were $0.07 \mathrm{~mol} / \mathrm{kg}$ ad $130 \mathrm{mg} / \mathrm{kg}$ respectively.

Figure 2 below shows the rank abundance plot of land molluscs in Ngel- Nyaki forest reserve. The plot showed that a few species were very abundant, a few very rare, but most species had relative abundance. Two species had more than 100 individuals; three species with over 50 individuals, eight species with more than 10 individuals, while the remaining five species had less than ten individuals.

The dendogram showed the similarities/dissimilarities between land snail species recorded from Ngel-Nyaki forest reserve. Based on the dendogram, the species are divided into two main groups as shown in figure 3 . 
93 | International Journal of Scientific and Management Research 4(7) 88-102

Table 1: List of mollusc species collected from Ngel-Nyaki forest reserve during the study period

\begin{tabular}{|c|c|c|c|c|c|c|c|c|c|c|c|c|c|c|c|c|c|c|c|c|c|c|c|c|c|}
\hline FAMILY/ SPECIES & 1 & 2 & 3 & 4 & 5 & 6 & 7 & 8 & 9 & 10 & 11 & 12 & 13 & 14 & 15 & 16 & 17 & 18 & 19 & 20 & 21 & 22 & 23 & 24 & \\
\hline \multicolumn{26}{|l|}{ ACHATINIDAE } \\
\hline Callistoplepa sp. & - & 2 & 2 & - & - & - & 2 & 1 & - & 1 & 2 & 1 & 1 & 1 & 2 & - & 4 & - & 7 & 6 & - & 9 & 1 & 3 & 45 \\
\hline Limicolaria aurora & - & 1 & 1 & - & - & - & 1 & - & 1 & - & - & - & - & - & - & 1 & - & - & - & - & 1 & - & 1 & - & 7 \\
\hline Limicolaria sp & - & 2 & 2 & - & - & 2 & - & 2 & - & 1 & - & - & 2 & - & - & - & - & 2 & - & - & 2 & - & - & 2 & 17 \\
\hline \multicolumn{26}{|l|}{ ALLYIDAE } \\
\hline Aillyia camerunensis & 1 & - & - & - & 2 & - & - & 2 & - & - & - & 1 & - & - & 1 & - & - & 2 & - & 3 & - & 2 & - & 2 & 16 \\
\hline \multicolumn{26}{|l|}{ STREPTAXIDAE } \\
\hline Gulella cf. gemma & 1 & - & - & 1 & - & - & 1 & - & - & 2 & - & - & - & 1 & - & - & 2 & - & - & - & 1 & - & 2 & - & 11 \\
\hline Gulella cf. monodon & - & - & - & - & - & - & 1 & - & 2 & - & - & - & 1 & - & - & - & - & - & - & - & - & - & - & 2 & 6 \\
\hline Ptychotrema anceyi & - & - & - & - & - & - & - & - & - & - & 1 & - & - & - & 2 & 5 & 5 & 6 & 2 & 4 & 5 & 4 & - & 5 & 39 \\
\hline Streptostele sp. & 1 & - & 2 & - & - & 2 & - & - & 1 & - & - & 2 & - & - & - & - & 2 & - & - & - & - & - & 3 & 2 & 15 \\
\hline Tomostele musaecola & - & 2 & - & - & - & - & - & - & - & 2 & - & - & - & - & - & - & 2 & - & - & 2 & - & - & 2 & 2 & 12 \\
\hline \multicolumn{26}{|l|}{ SUBULINIDAE } \\
\hline Curvella cf. feai. & - & - & - & - & - & - & - & 3 & - & - & 1 & - & 3 & 4 & 1 & - & 4 & - & 6 & 5 & - & 3 & 4 & - & 34 \\
\hline Kempioconchia stuhlmanni & 2 & 5 & 5 & - & - & - & - & - & 5 & - & - & - & 2 & - & - & - & 5 & - & 2 & - & - & 5 & - & - & 31 \\
\hline Pseudoglessula sp. & 2 & - & - & - & - & - & - & - & - & - & - & 1 & - & - & - & - & - & 2 & - & - & 1 & - & - & 1 & 7 \\
\hline Subulina sp. & 12 & 43 & 19 & - & - & 1 & - & - & - & 5 & - & - & - & - & - & 12 & - & - & - & 11 & - & - & - & 13 & 116 \\
\hline Subulona cf inroluta & 1 & - & 24 & 2 & 1 & 1 & - & 9 & - & - & - & 5 & - & 6 & - & 8 & - & 9 & - & - & 5 & - & 7 & - & 78 \\
\hline
\end{tabular}


94 | International Journal of Scientific and Management Research 4(7) 88-102

\section{UROCYCLIDAE}

Gymnarion sp.

Thapsia oscitans

$\begin{array}{llll}4 & 8 & 8 & 10\end{array}$

$\begin{array}{rrrrr}7 & 9 & 5 & 4 & 5 \\ - & 1 & 3 & 5 & 4\end{array}$

VERONICELLIDAE

Pseudoveronicella liberiana 1

\section{RACHISTIDAE}

Bulunaloid cunella (large)

Total No. of ind. Per plot 29

Total No. of sp. Per plot

455

$\begin{array}{rr}4 & 9 \\ - & -\end{array}$

$\begin{array}{lll}6 & 2 & 9 \\ - & - & 4\end{array}$

10

$\begin{array}{lllllll}12 & 19 & 7 & 9 & 10 & 12 & 187\end{array}$ 1

$-\quad-1$

$\begin{array}{llllllllllllllllllllllllllllllllllllllll}- & - & 2 & - & - & - & - & - & - & - & - & - & 1 & - & - & - & - & 2 & - & - & 1 & - & - & 2 & 8 \\ 29 & 68 & 70 & 13 & 12 & 14 & 15 & 25 & 18 & 20 & 9 & 19 & 11 & 18 & 9 & 39 & 32 & 33 & 31 & 51 & 26 & 37 & 35 & 47 & 681 \\ 10 & 8 & 10 & 3 & 3 & 6 & 6 & 7 & 6 & 7 & 5 & 6 & 7 & 5 & 6 & 6 & 8 & 7 & 6 & 8 & 9 & 7 & 9 & 12 & \end{array}$

Table 2: Values of Soil Parameters Analysed from Mambilla Plateau Montane Forest, Ngel Nyaki

\begin{tabular}{|c|c|c|c|c|c|c|c|c|c|c|c|}
\hline \multirow[t]{2}{*}{ Parameters } & $\mathrm{pH}$ & Org & Total N & Avail P & Exc Acidity & $\mathrm{K}$ & $\mathrm{Ca}$ & $\mathrm{Mg}$ & $\mathrm{Na}$ & ECEC BS & $\%$ Clay \\
\hline & $\mathrm{H}_{2} \mathrm{O}$ & $\mathrm{g} / \mathrm{kg}$ & $\mathrm{g} / \mathrm{kg}$ & $\mathrm{mg} / \mathrm{kg}$ & $\mathrm{Cmol} / \mathrm{kg}$ & \multicolumn{2}{|c|}{$\mathrm{Cmol} / \mathrm{Kg}$} & \multicolumn{2}{|c|}{$\mathrm{Cmol} / \mathrm{Kg}$} & $\mathrm{Cmol} / \mathrm{Kg}$ & $\mathrm{Cmol} / \mathrm{Kg}$ \\
\hline Values & 5.3 & 59.33 & 7.25 & 130 & 3.83 & 9.52 & 0.07 & 0.05 & 0.05 & 13.5371 .67 & 6.5 \\
\hline
\end{tabular}


95 | International Journal of Scientific and Management Research 4(7) 88-102

Table 3: Abundance, percent individuals and number of mollusc species collected from Ngel-Nyaki forest reserve during the study period.

\begin{tabular}{lcccc}
\hline Family & $\begin{array}{c}\text { Number of } \\
\text { Species }\end{array}$ & \% Species & $\begin{array}{c}\text { Number of } \\
\text { Individual }\end{array}$ & \% Individuals \\
\hline Achatinidae & 3 & 16.67 & 69 & 10.13 \\
Allyidae & 1 & 5.56 & 16 & 2.35 \\
Streptaxidae & 5 & 27.78 & 83 & 12.19 \\
Urocyclidae & 2 & 11.11 & 231 & 33.92 \\
Subulinidae & 5 & 27.78 & 266 & 39.06 \\
Veronicellidae & 1 & 5.56 & 8 & 1.17 \\
Rachistidae & 1 & 5.56 & 8 & 1.17 \\
Total & $\mathbf{1 8}$ & & $\mathbf{6 8 1}$ & \\
\hline
\end{tabular}

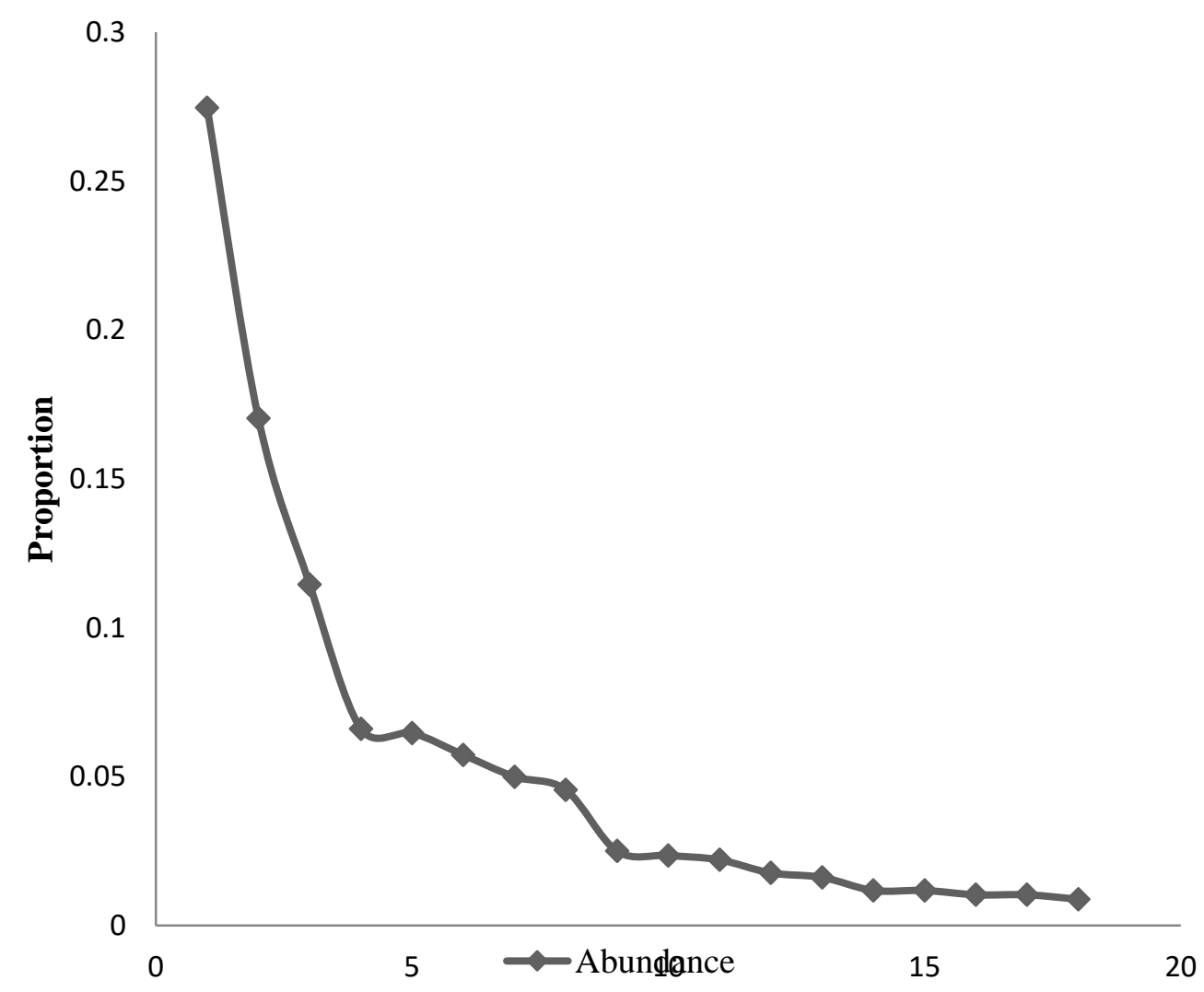

Figure 2: Rank abundance curve of land molluscs recorded from Ngel-Nyaki forest reserve during the study period 


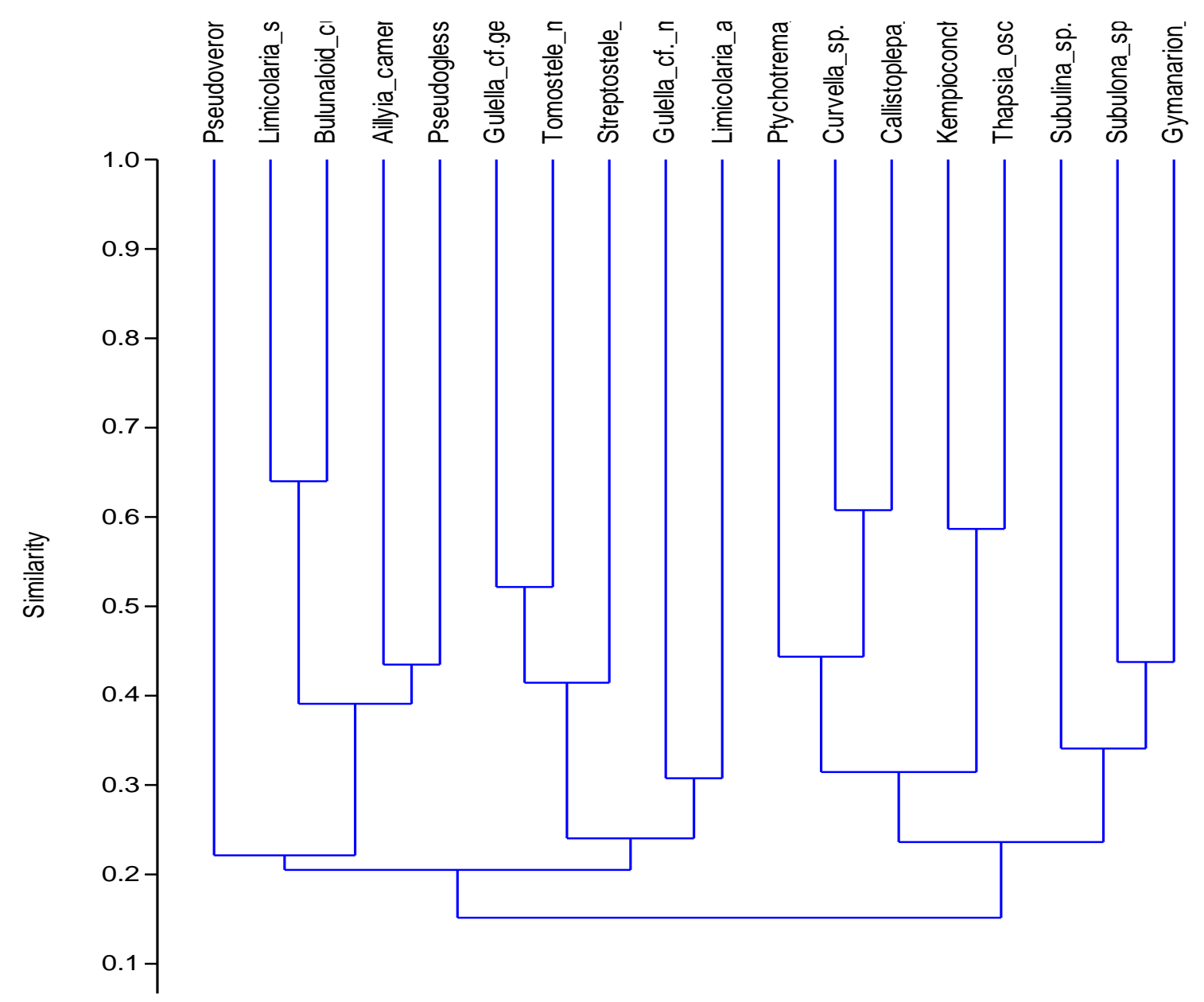

Figure 3: Dendogram of similarities/dissimilarities using Bray-Curtis index between
land Mollusc recorded from Ngel- Nyaki forest reserve during the study

\section{Discussion and Conclusions}

This study describes the species richness and diversity of land snails in NNFR. A total of 681 specimens comprising of 18 species belonging to seven molluscan families were collected. The plots yielded 3 to 12 species. This showed that the molluscs were moderately diverse in the study sites. The families Streptaxidae (carnivores) and Family Subulinidae (herbivores) dominated the mollusc fauna in Mambilla Plateau montane forest with 5 species each. At the Mambilla Plateau Montane forest, the Chao 2 and Jackknife estimator were 17.99 and 18.10, respectively of all sample collected and the Whittaker Index was 1.587, also indicating a low amount of differentiation in species composition among the plots.

This study has revealed that the land mollusc fauna of NNFR are relatively diverse with low densities. It has shown that not all the sampling areas of the reserves had much species. Most of the species recorded in this study had been recorded elsewhere in Nigeria and comparatively, the numbers of species recorded are lower than those recorded in other parts of Nigeria. For example, Oke and Chokor (2010) recorded 36 species from 9 molluscan families. In an earlier study at Ehor, Edo State, Nigeria by Oke and Alohan (2004), 38 species and 1258 individuals were recorded from nine 20 metres squared plots in a tropical rainforest. In another study at the Okomu National Park, Edo State, Nigeria, Oke and Alohan (2002) collected 35 species and 316 individuals from five 20 metre squared plots. In an investigation 
carried out at Odukpani in Cross River State, 52 species and 425 individuals were collected during one study (Oke et al., 2007). This shows that the diversity of molluscs found in Taraba State is low compared to those from the southern part of Nigeria.

Gymnarion sp. was the most abundant species with 187 individuals belonging to the family Urocyclidae in Ngel-Nyaki. In contrast, other studies on mollusc fauna in Nigeria reported that family Urocyclidae rarely dominates other species, as observed in an Oil palm and rubber plantations in Edo State. In a secondary forest at Ekpoma, Edo State and in a Cocoa plantation at Usen Edo State, the family Streptaxidae dominated while Subulinidae and Streptaxidae were the dominant mollusc fauna in the Agro-forest in Ile-Oluji, Ondo State and at Omo Forest Reserve in Ogun State (Oke et al., 2007, 2008 and Oke, 2013).

The number of land snail individuals recorded in Ngel-Nyaki were however, higher than that recorded in some locations in the southern part of Nigeria. For instance, 242 individuals were recorded in Obudu Cattle Ranch, 425 in Odukpani and 636 in Oban Hills Sector, all in Cross River State, Nigeria (Oke et al., 2004, 2007). This difference could be attributed to the fact the number of sampling plots were more in this study compared to the plots examined in those locations, except in Oban Hills, where samples were collected from 24 sampling plots. All the species named and identified in this study are common or have been recorded in the southern and western part of Nigeria and also Africa in general. It could be that the species that were not recorded are inhabitants of other areas in the park and montane forest, which were not sampled.

The rank abundance curve showed that there was a dramatic reduction in the number of species in the study areas and a marked increase in the dominance of a few species and unevenness of the overall distribution..

With regards to the quality of soil from the sites studied, the $\mathrm{pH}$ of the soil at NNFR was a little less acidic (5.3) similar to the value (5.19) recorded at Idanre (Oke, 2012). Studies have shown that land snail faunas in acidic habitat are more depauperate in species and individual numbers compared to those in neutral or calcerous soils (Emberton et al., 1997; Winter-De and Gittenberger, 1998; Nekola, 2010). Although the calcium content of the soil of MPMF was $0.69 \mathrm{molkg}^{-1}$. This shows that other factors other than calcium content were responsible for snail abundance because, some studies have shown that, the higher the soil calcium content the more the snail abundance. For example, in studies undertaken by various investigators (Baker and Mayhill, 1999; Nekola and Smith, 1999; Hotopp, 2002; Lange, 2003; Terbraak, 1994 and Ondina et al, 1998) snail abundance correlated significantly and positively with soil calcium. Based on Detrended Correspondence Analysis (DCA), the most important soil factors affecting the abundance and distribution of snails are calcium, $\mathrm{pH}$ and texture. Several authors have however noted that $\mathrm{pH}$ and calcium are the most important factors (Lange, 2003).

This study has provided information on the species richness and diversity pattern of land mollusc in NNFR. This information will assist conservation agencies in protecting the integrity of the species recorded, especially those that are of moderate abundance, of which, if steps are not taken may face extinction.

\section{Conclusion}

The findings of this study have provided the first inventory of land molluscs in NNFR. One species from MPMF was being recorded for the first time in Nigeria, and it may possibly be a new species. Furthermore, it has provided basic data on diversity and abundance of species, 
and revealed species present. This knowledge will help reserve managers to monitor the populations of various species that may be threatened in the future as well as assist conservation planners in incorporating invertebrates, particularly land snails in reserve selection and management.

\section{References}

1) Aravind, N. A. (2005). Ecology of Land Snails of Western Ghats. PhD Thesis, Department of Applied Zoology, Mangalore University, Mangalore. Pp. 182.

2) Bar-Yosef Mayer, D. E. (2002). Archaeomalacology: Molluscs in former environments of human behavior (1. An Introduction to Archaeomalacology). 9th ICAZ Conference, Durham.

3) Baur, B. and Baur, A. (1993). Climatic warming due to thermal radiation from an urban area as possible cause for the local extinction of a land snail. Journal of Applied Ecology. 30: 333-340.

4) Bezemer, M. T. and Knight, K. J. (2001). Unpredictable responses of garden snail (Helix aspersa) populations to climate change. Acta Oecologica. 22: 201-208.

5) Bouchet, P. and Rocroi, J. (2005). Classification and nomenclature of Gastropods. Malacogia. 47 (1-2): 251-275.

6) Čejka, T. and Hamerlík, L. (2009). Land snails as indicators of soil humidity in Danubian woodland (SW Slovakia). Polish Journal of Ecology. 57: 741-747

7) Centre for Education, Research and Conservation of Primates and Nature (CERCOPAN) (2011). Annual report. Web: www.cercopan, org. Pp. 2-10.

8) Clarke, K. R. (1993). Non-parametric multivariate analyses of change in community structure. Australian Journal of Ecology. 18: 117-143.

9) Clark, J. A. and May, R. M. (2002). Taxonomic bias in Conservation Research. Science. 297: 191-192.

10) Codington, J. A., Young, L. H. and Coyle, F.A. (1996). Estimating spider species richness in a southern Appalachian cove hardwood forest. Journal of Arachnology. 24: 111-128.

11) Colwell, R. K. and Coddington, J. A. (1994). Estimating terrestrial biodiversity through extrapolation. Philosophical Transactions of the Royal Society (Series B). 345: 101-118.

12) Colwell, R. K. (2006). Estimates: Statistical estimation of species richness and shared species from samples. Version 7.5. User's Guide and application. http://purl.oclc.org/estimates (accessed 26/03/2013).

13) Deepak, V., Vasudevan, K. and Pandav, B. (2010). Preliminary observation on the diet of the cane turtle (Vijayachelys silvatica). Hamdaryad. 34: 166-168.

14) Dunk, J. R., Zielinski, W. J. and Preisler, H. K. (2004). Predicting the occurrence of rare mollusks in Northern California forests. Ecological Applications. 14: 713-729.

15) Emberton, K. C. (1997). Land snail community morphologies of the highest-diversity sites of Madagascar, North America, and New Zealand, with recommended alternatives to height-diameter plots. Malacologia. 36: 43-66.

16) Ezealor, A. U. (2002). Critical sites for biodiversity conservation in Nigeria. Nigerian Conservation Foundation, Lagos. Pp. 110.

17) Fontaine, B., Gargominy, O. and Neubert, E. (2007). Land snail diversity of the savanna/forest mosaic in Lopé National Park, Gabon. Malacologia. 49: 313-338.

18) Fretter, V. and Peake, J. (1978). Pulmonates: Systematics, Evolution and Ecology. Volume 2A. Academic Press. London. Pp 50-335. 
19) Gargominy, O. and Ripken, T-H. E. J. (1998). Micropulmonates in tropical rainforest litter: a new bio-jewel. In: Abstracts, World Congress of Malacology, Washington, D. C. (R. Bieler \& P.M. Mikkelsen, eds), 116. Field Museum of Natural History, Chicago.

20) Gauch, H. G. and Whittaker, R. H. (1981). Hierarchical classification of community data. Journal of Ecology. 69: 537-557.

21) Gerlach, J. (2007). Short-term climate change and the extinction of the snail Rhachistia aldabrae (Gastropoda: Pulmonata). Biology Letters. 3: 581-585.

22) Graveland, J. R., Van der Wal, J. H., Van Balen. and Van noordwijk, A. J. (1994). Poor reproduction in forest passerines from decline of snail abundance on acidified soils. Nature. 368: 446-448.

23) Gotelli, N. and Colwell, R. K. (2001). Quantifying biodiversity: procedures and pitfalls in the measurement and comparison of species richness. Ecology Letters 4: 379-391.

24) Hammer, O., hArPer, d.A.T. \& ryAn, P.d. 2001. PAST: Paleontological Statistics Software package for education and data analysis. Palaeontologia Electronica 4 (1): $1-9$.

25) Hayward, P. J. (1996). Handbook of the marine fauna of North-west Europe. Oxford University Press. Pp. 484-628.

26) Horsák, M., Lososová, Z., Čejka, T., Juřičková, L. and Chytrý, M. (2013) Diversity and Biotic Homogenization of Urban Land-Snail Faunas in Relation to Habitat Types and Macroclimate in 32 Central European Cities. PLoS ONE. 8(8): 71783.

27) Ibimilua, A. F. 2013. Biodiversity-Ecosystem Management and Sustainable Development in Ekiti State, Nigeria. British Journal of Humanities and Social Sciences 9. (1): $35-45$.

28) Isikhuemen, E. M. and Iduozee, O. F. (2010) Degraded forests in protected landscapes: prospects for biodiversity rehabilitation in Urhonigbe forest reserve, Edo State, Nigeria. Traditional Forest-Related Knowledge and Sustainable Forest Management in Africa. IUFRO World Series. 23: 199 - 206.

29) Janus, H. (1965). Molluscs. Burke Publishing Company Limited. 14 John Street, London W.C.I. Pp 5-179.

30) Kay, E. A. (1995). Which molluscs for extinction? The conservation biology of molluscs. Proceedings of a symposium held at the 9th International Malacological Congress. UCN/SSC Mollusc Specialist Group. Pp. 1-7.

31) Kerney, M. P. and Cameron, R. A. D. (1979). A field guide to the land snails of Britain northwestern Europe. Collins, London. Pp. 288.

32) Kuuder, C. W., Bagson, E. and Aalangdong, I. O. (2013). Assessment of Visitor Satisfaction in Mole National Park, Ghana. African Journal of Hospitality, Tourism and Leisure. 2: 3.

33) Loker, E. S. (2005). Research on the intermediate hosts for schistosomiasis: What are the

priorities? Presentation to the scientific working group on schistosomiasis. World Health.

34) Lydeard, C., Cowie, R.H., Ponder, W, F., Bogan, A. E., Bouchet, P., Clark, S. A., Cummings, K. S., Frest, T. J., Gargominy, O., Herbert, D. G., Hershler, R., Perez, K. E., Roth, B., Seddon, M., Strong, E. E. and Thompson, F. G. (2004). The Global Decline of Non-marine Molluscs. BioScience. 54: 321-330. 
35) Mittermeier, R. A., Myers, N., Thomsen, J. B., Fonseca, G. A., and Olivieri. S. (1998). Biodiversity hotspots and major tropical wilderness areas: approaches to setting conservation priorities. Conserv. Biol. 12: 516-520.

36) Naggs, F. and Raheem, D. (2007). Tropical Landsnail Diversity. The Darwin Initiative. The Natural History Museum, London. www.nhm.ac.uk/jdsml/researchcuration/.../tropical-landsnail. (Accessed: November 2011).

37) Nathaniel, I. T. and Nathaniel, A. (2001). The effect of poverty in conservation of biodiversity; The Nigerian's Experience.

38) Nigeria National Park Service (NPS) (2006). Information Booklet, Published by NPS. Pp. 48

39) Nigerian Conservation Foundation (NCF). (2002). Protected gazetted and proposed in Nigerian Conservation Foundation report.

40) Nigerian Montane Forest Project, (NMFP). (2016). Annual report, www.afromontane.canterbury.ac.nz.

41) Oke, O. C. (2007). Land snail diversity in a patch of cocoa plantation in Erin-Ijesha hills, Osun State, Nigeria. African Scientist. 8(2): 61-68.

42) Oke, O. C. (2012). Land snail diversity in post extraction secondary forest reserves in Edo state, Nigeria. African Journal of Ecology. 51: 244-254.

43) Oke, C. O. (2013). Terrestrial mollusk species richness and diversity in Omo forest reserve, Ogun state, Nigeria. African Invertebrates. 54(1): 93-104.

44) Oke, O. C. and Alohan, F. I. (2006). The land snail diversity in a square kilometre of tropical rainforest in Okomu National Park Service. 2006. Information Booklet, Published by NPS. Pp. 48.

45) Oke, O. C., Alohan, F. I., Uzibor, M. O. and Chokor, J. U. (2008). Land snail diversity and species richness in an oil palm agroforest in Egbeta, Edo State, Nigeria. Bioscience Research Communications. 20(5): 249-256.

46) Oke, C. O. and Alohan, F. I. (2002). The land snail diversity in a square kilometer of tropical rainforest in Ehor, Edo State Nigeria: modest species richness, high abundance and local homogeneity. Journal of Environmental, Science \& Health. 5: $39-43$.

47) Oke, C. O. and Alohan, F. I. (2004). The land snail diversity in a patch of rainforest in Cross river National parks: high species richness abundance and heterogeneity. Nigerian Journal of Applied poScience. 22: 166-173.

48) Oke, C. O. and Alohan, F. I. (2006). The land snail diversity in a square kilometer of tropical rainforest in Okomu National park Edo State Nigeria. African Science. 7: 135142.

49) Oke, C. O. and Chokor, J. U. (2009). Land snail populations in a shade and full-sun cocoa plantations in South-Western Nigeria, West African. African Scientist. 10(1): 19-29

50) Oke, O. C., Alohan, F. I., and Edosomwan, E. U. (2007b). Land snail diversity and abundance in a patch of secondary tropical rainforest in Ekpoma, Edo State, Nigeria. African Scientist. 8(2): 55-60.

51) Oke, O. C. and Omoregie, C. E. (2012). The land snail diversity in a cocoa agro-forest in Ile-Oluji, Ondo State, Nigeria. The Zoologist. 10: 40-47.

52) Oke, O. C. and Ugiagbe, O. O. (2007). Land snail diversity in a patch of cocoa plantation in Usen, Edo State, Nigeria. Global Journal of Pure and Applied Sciences. 13(4): 481-485.

53) Oke, O. C., Alohan, F. I., Uzibor, M. O. and Chokor, J. U. (2008). Land snail diversity and species richness in an oil palm Agro-forest in Egbeta, Edo State, Nigeria. Bioscience Research Communications. 20(5): 249-256. 
54) Örstan, A., Pearce, T. A. and Welter-Schultes, F. (2005). Land snail diversity in a threatened limestone district near Istanbul, Turkey. Animal Biodiversity and Conservation. 28(2): 181-188.

55) Pounds, J. A. and Crump, M. I. (1994). Amphibian declines and climate disturbance: the case of the golden toad and the harlequin frog. Conservation Biology. 8: 72-85.

56) Pounds, J. A., Fogden, M. P. L. and Campbell, J. H. (1999). Biological response to climate change on a tropical mountain. Nature. 398: 611-615.

57) Raheem, C. D., Naggs, F., Preece, R. C., Mapatuna, Y., Kariyawasam, L. and Eggleton, P. (2008). Structure and conservation of Sri Lankan land-snail assemblages in fragmented lowland rainforest and village home gardens. Journal of Applied Ecology. 45: 1019-1028.

58) Rajashekhar, K. P. and Aravind, N. A. (2012). Perturbation in the pattern of land snail diversity due to anthropogenic disturbance to wet evergreen forests of the Western Ghats, India. In: Priyadarsanan, D. R., Devy, M. S., Subramanian, K. A., Aravind, N. A. and Seena, N. (eds). Invertebrate Diversity and Conservation in the Western Ghats. ATREE, Bangalore.

59) Rao, P. Y., Murthy, N. L. N. and Kishore. S. (2013). Diversity of Molluscs in Chittoor District of Andhra Pradesh with Special Reference to Tirumala Hills, India. International Journal of Advanced Scientific and Technical Research. 2 (3): 573-580.

60) Schilthuizen, M. and Rutjes, H. A. (2001). Land snail diversity in a square kilometre of tropical rainforest in Sabah, Malaysian Borneo. Journal of Molluscan Studies. 67: 417-423.

61) Seddon, M. B., Tatterfield, P., Herbert, D. G., Rowson, B., Lange, C. N., Ngereza, C., Warui, C. M. and Allen, J. A. (2005). Diversity of African forest mollusk faunas: what we have learned since

62) Shimek, B. (1930). Land Snails as Indicators of Ecological Conditions. Ecology. 11: 673-686.

63) Soberón, J., Jiménez, R., Golubov, J. and Koleff, G. (2007). Assessing completeness of biodiversity databases at different spatial scales. Ecography. 30: 152-160.

64) Sodhi, N. S. (2008). Tropical biodiversity loss and people-a brief review. Basic and Applied Ecology. 9: 93-99.

65) Solem (1984). Records of the Western Australian Museum Supplement 68: 103-113.

66) Shell Petroleum Development Company. (2006b). Biodiversity Action Plan Manual for Gilli-gilli Forest Reserve, Edo State, Nigeria. The Shell Petroleum Development Company, Nigeria. Pp. 52.

67) Sternberg, M. (2000). Terrestrial gastropods and experimental climate change: A field study in a calcareous grassland. Ecological Research. 15: 73-81.

68) Tattersfield, P. (1996). Local patterns of land snail diversity in a Kenyan rain forest. Malacologia. 38: 161-180

69) Tattersfield, P. (1997). Biodiversity and Conservation of Land Molluscs (Snails and Slugs) of orests of Tanzania. Contribution No. 2 - Studies in Eastern Arc Forests. Unpublished progress report to Tanzania Commission for Science and Technology, Dar es Salaam, Tanzania.

70) Tattersfield, P., Seddon, M., Meena, C., Kayumo, N and Kasigwa, P. (1998). Ecology ad Conservation of the Landsnails of the Easter Arc Mountains. Journal of East Africa natural History, 87(1), 119-138, 120.

71) Thomas, C. D., Cameron, A., Green, R. E., Bakkenes, M., Beaumont, L. J., Collingham, Y. C., Erasmus, B. F. N., de Siqueira, M. F., Grainger, A., Hannah, L., Hughes, L., Huntley, B., van Jaarsveld, A. S., Midgley, G. F., Miles, L., Ortega- 
Huerta, M. A., Peterson, A. T., Phillips, O. L. and Williams , S. E. (2004). Extinction risk from climate change. Nature. 427: 145-148.

72) Warui, C. (1998). Diversity, Species Composition and some Ecological Aspects of Terrestial Molluscs in Mount Kenya National Park-Kenya. M.Sc Thesis, University of Nairobi.

73) Welter-Schultes, F. W. and Williams, M. R. (1999). History, Island Area and Habitat availability determine land snail species richness of Aegean Islands. Journal of Biogeography. 26(2): 239-249.

74) Winter, A. J. De and Gittenberger, E. (1988). The land snail fauna of a square kilometre patch of rainforest in southwestern Cameroon: high species richness, low abundance and seasonal fluctuations. Malacologia. 40: 231-250. 